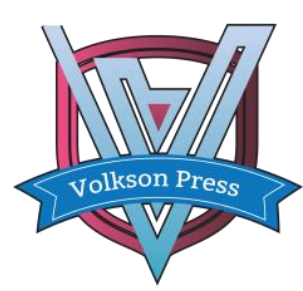

Contents List available at VOLKSON PRESS

Economics \& Management Innovations(EMI)

DOI : http://doi.org/10.26480/icemi.01.2017.54.55

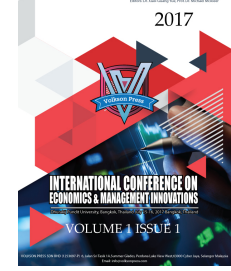

\title{
Conceptual Research Framework Currency Analysis of Some Countries In East Asia Against Southeast Asia
}

\author{
Teguh Sugiarto 1, Prof. Ubud Salim, MA 2, Prof,.Ghozali Maski, M.Si ${ }^{3}$ Dr. Siti Aisjah, MM ${ }^{4}$ \\ 1)*Doctoral Student Management FEB Univ. Brawijaya, lecture Universitas Budi luhur and AAJ JayabayaJakarta, Indonesia, 12260 \\ 2, 3, 4) Doctoral Program at Doctoral Management and Business in Economics, Faculty of Economics Brawijaya University, Jakarta, Indonesia \\ * teguh_cpconsulting@yahoo.com \\ This is an open access article distributed under the Creative Commons Attribution License, which permits unrestricted use, distribution, and reproduction in any \\ medium, provided the original work is properly cited.
}

\section{ARTICLE DETAILS}

\section{Article History:}

Received 02 october 2017

Accepted 06 october 2017

Available online 11 october 2017

Keywords:

SVAR, Currency Value, Bernanke-

Mihov Matrix, Southeast-East Asia.

\section{ABSTRACT}

The purpose of this research is to propose a large scale Structural VAR model analysis with matrix form I (1) and I $(0,5)$. The proposed research method, using the SVAR matrix basis Bernanke-Mihov (1998), with case studies of currency values of several countries in southeast asia and eastern asia, only identifies assumptions. Prior to testing with the SVAR model performed, first the ADF time series test data, Selection Lags test, cointegration test and diagnostic test. From the research to be conducted, it can be concluded that the model in the proposal, can provide comparative results from the use of matrix model. The update of this research lies in the use of matrices I (1) and I $(0,5)$.

\section{INTRODUCTION.}

The Asian economic crisis of 1997-1998 has had an indirect impact on the economies of several countries in East and Southeast Asia. Some countries in Asia such as the People's Republic of China (PRC); Taipei, including Indonesia, Kazakhstan, Philippines, Thailand, Hongkong, India; Republic of Korea; Singapore; And Viet Nam began anticipating currency movements in their respective countries since September 2008. This is due to the declining value of the currencies of developing countries in Asia, especially in Southeast Asian countries such as Indonesia, Thailand, The Philippines and Malaysia against the United States dollar exchange rate. This is not accompanied by the occurrence of currency weakness in countries in the eastern Asian region such as Japan, Hong Kong, China and Korea. This study analyzes the currency values of several countries in East Asia and some countries in Southeast Asia, by imposing short-term, short-term restrictions arising from economic theory in the SVAR methodology of the Bernanke-Mihov Model pioneered by Bernanke-Mihov (1998) [1]. This research needs to be done to provide a comprehensive picture of what is known about the effectiveness of foreign exchange in developing and emerging countries in Asia. This is done in two steps. First, an extensive review of the literature on this topic is conducted. Second, new evidence of systematic study in the context of a country state in east and southeast Asia. Using the time series data presented in the appendix. In constructing an overview of the results, it is therefore useful to combine the available evidence with considerable literature from developed countries and to take into account specific institutional differences that can lead to substantial differences.

\section{II.LITERATURE REVIEW}

Research conducted by Clarida and Gali (1994) [2] is one model of analysis that produces output in model building using three VARstructural variables, the model uses the relative variables of price, real exchange rate, and unemployment rate, for Identified three types of macroeconomic shocks: supply, demand, and nominal shocks. The contribution of each type of shock variability and each of the other variables is assessed later. Canzoneri, et al, 1996 (3), Chadha and Prasad (1997) [4], and Thomas (1997) [5] also use the same approach to exchange-rate learning resources as well as fluctuation rates of production in industrialized countries In the study.
If you look to the studies done in Asian and Latin American States Clarida and Gali, (2002) [6]; Ender (2010) [7], Dibooglu and Kutan (2001) [8]; Kakinaka, et al, (2010) [9] describes exchange rate variations in Country Country in the Asian region, where there are great real and nominal shocks, which follow the methods used previously. They assume that real and nominal exchange rates will be subject to real and nominal shocks. However $\mathrm{Ha}$ et al (2007) [10] says that, the terms trade, productivity, and government spending are real shocks. Kakinaka, et al, (2010) [9], argues that with technological change and preference can be caused by real shocks, however the change of nominal macroeconomic variables, such as money supply, will be regarded as a nominal shock. So they define real shocks as changes in productivity, technology and economic structure. And on the other hand, changes in the price level, money supply can also be considered a nominal shock. Blanchard and Quah (1989) [11]; And Ender (2010) [7] use a long-term restriction model to obtain structural vector autoregresion (SVAR) from standard model autoregressive (VAR) vectors. And the series is decomposed into short-term and long-term analysis, but in the long-term component of SVAR implementation, the paper examines how the real and nominal exchange rates in Asian countries studied ie Vietnam can see the response of real and nominal shocks. This method is also used by Clarida and Gali, (2002) [6]; Ender and Lee, (1997) [12]; Chen and Wu, (1997) [13]; Dibooglu and Kutan (2001) [8].

\section{III.RESEARCH CONCEPTUAL FRAMEWORK}

This study will use the SVAR method based on identification techniques developed by Bernanke and Mihov (1998) [1] for currency exchange rates of 4 countries in eastern Asia and 4 countries in Southeast Asia to US dollar during period of 2004-2014 daily data . The authors make the methodological estimation framework in this study from the model built by Blanchard and Perotti (1999) [14], but this BP model is widely used in fiscal and non-monetary applications. The research framework developed in this study, with the assumption that the applied model is a closed economy model for a currency exchange rate in East Asia and Southeast Asia.

\section{IV.RESULT AND CONCEPTUAL FRAMEWORK}




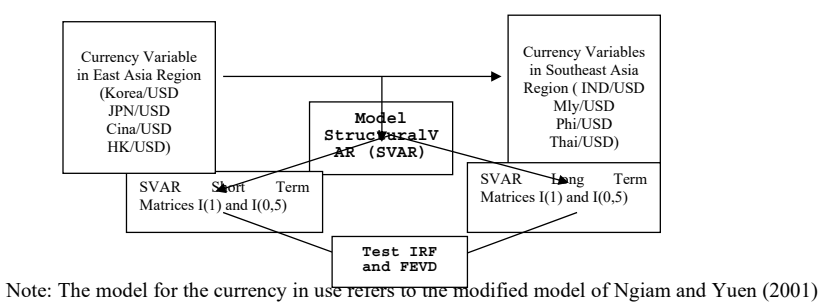

[15], Eichengreen and Bayoumi (1999) [16], Wyplosz (2001) [17] for the Euro area. The Structural VAR model used in this study is a non recursive model from Bernanke and Mihov (1998) [1], with a method of just identification.

\section{Reference}

[1] Bernanke, B., dan Mihov, I., Measuring Monetary Policy. Quarterly Journal of Economics, 113, 869_902, (1998).

[2] Clarida, R. \& Gali, J, Sources of Real Exchange Rate Fluctuations: How Important are Nominal Shocks? NBER Working Papers, 4658, 1-84, (1994).

[3] Canzoneri, M., J. Valles, dan J. Vinals, "Do Exchange Rates Move to Address International Macroeconomic Imbalances?" CEPR Discussion Paper No. 1498 (London: Centre for Economic Policy Research). (1996).

[4] Chadha, B, dan Eswar Prasad, "Real Exchange Rate Fluctuations and the Business Cycle: Evidence from Japan," IMF Staff Papers, Vol. 44, No. 3. (1997),

[5] Thomas, A, "Is the Exchange Rate a Shock Absorber? The Case of Sweden," IMF Working Paper 97/176 (Washington: International Monetary Fund). (1997).

[6] Ender, Applied econometrics time series, 3th edition, p272 -349, John Willey \& Sons.(2010).

[7] Wyplosz, C.” A Monetery Uion In Asia ? Some Europen Lessons,"Unpublished manuscript Graduate Institute for International Studies, Geneva, Avalaible at http://www.rba.gov.au/ Publicationandresearch/Cnfrence/2001/wyplosx.pdf,(1999).
[8] Kakinaka, M, et, al, Real shock or nominal shock? Exchange rate movements in Cambodia and Lao PDR. The Singapore Economic Review, vol. 55, no.4, p.685 - 703. (2010).

[9] Ha, I, Lee, B dan Cheong, C, What caused the Korean currency crisis in 1997?: Weak fundamentals or self-fulfilling expectations. Asian Economic Journal, vol.21, p.195 - 206.(2007)

[10] Blanchard, O.J. dan Quah, D, J. A Traditional Interpretation of Macroeconomic Fluctuations, American Economic Review, 79, 1146- 1164. (1989).

[11] Enders, W dan B Lee, Accounting for real and nominal exchange rate movements in post-Bretton Woods period. Journal of International Money and Finance, vol.16, p.233 - 254.,(1997).

[12] Chen, Show-Lin, dan Jyh-Lin Wu, "Sources of Real Exchange Rate Fluctuations: Empirical Evidence from Four Pacific Basin Countries," Southern Economic Journal, Vol. 63, No. 3, pp. 776-787. (1997),

[13] Blanchard, O. J. dan Perotti, R, "An Empirical Characterization of the Dynamic Effects of Changes in Government Spending and Taxes on Output" [online]. NBER Working Paper Series, No. 7269. Available from:[http://www.nber.org/papers/ w7269.pdf]. (1999).

[14] Bernanke, B. dan Blinder, A. The Federal Funds Rate and the Channels of Money Transmission, American Economic Review, 82, 901-921, (1992).

[15] Ngiam, Kee, J dan Yuen, H Monetery Cooperation in East Asia : A Way Forward,"Singapore Economic Review 46, pp.211-246, (2001).

[16] Eichengren, Barry dan Bayoumi, "Is Asia an Optimum Currency Area ? Can It Become One ?" in S. Collignon, J. Pisani-Ferry dan Y.C Park, Eds. Exchange Rate Policies in Emerging Asian Countries. London : Routledge. Pp. 347-366. T (1999)

[17] Wyplosz, C." A Monetery Uion In Asia ? Some Europen Lessons,"Unpublished manuscript Graduate Institute for International Studies, Geneva, Avalaible at http://www.rba.gov.au/ Publicationandresearch/Cnfrence/2001/wyplosx.pdf,(1999). 